\title{
Job Design and Employee Absenteeism: A Case Study of Some Government Parastatals in Nigeria
}

\author{
Don-Solomon Amakiri, Godday Raymond Luke \\ Department of Business Administration and Management, Niger Delta University, Wilberforce Island, Bayelsa State, Nigeria
}

Email address:

donamaco52@gmail.com (Don-Solomon. A.),goddayluke99@gmail.com (G. R. Luke)

\section{To cite this article:}

Don-Solomon Amakiri, Godday Raymond Luke. Job Design and Employee Absenteeism: A Case Study of Some Government Parastatals in Nigeria. International Journal of Secondary Education. Special Issue: Teaching Methods and Learning Styles in Education.

Vol. 3, No. 6-1, 2015, pp. 67-71. doi: 10.11648/j.ijsedu.s.2015030601.11

\begin{abstract}
This empirical study examined the relationship between job design and employee absenteeism in Bayelsa State Civil Service, in a bid to proffering solution to the myriad of absenteeism in the ministries, this literature focused on dimensions such as job rotation and job enlargement and their relationship to absenteeism. A sample size of 348 workers from nineteen ministries was involved in the study. The data was analyzed with Spearman Rank Order Correlation Coefficient, whereas the impact of the moderating variable on the strength of relationship between the independent and depended variables was analyzed with Partial Correlation Coefficient. The findings from the study revealed that job enlargement and job rotation significantly relates to absence intensity. Base on the findings, it was recommended that organizations including ministries should take deliberate effort in designing job of its employee putting into consideration job enlargement and job rotation, as they are necessary ingredients that improves employee attendance rate thereby curtailing their level of absenteeism. it was also recommended that, employers should rotate employees from one job to the other to enable them acquire variety of skills and experience to make them have intrinsic satisfaction of their job that will in turn improve their commitment level to the organization including being regular and punctual to work.
\end{abstract}

Keywords: Job Design, Employee Absenteeism, Job Enlargement, Job Rotation, Absence Intensity

\section{Introduction}

The issue of employee absenteeism is a major problem that has attracted researches around the globe in a bid to proffering solution to its occurrence in the private and public sectors.

Employee absenteeism has a large effect on the bottom line of public and private organizations. Realizing that there is a problem and actively striving to develop a solution may have a large upfront cost but will ultimately save the organization a great deal over the long run. To underscore just how much employee absenteeism can cost an employer; the United State government released a report in June 2013 indicating that Federal civil servants missed work an average of 18 days per year in United State of America, which amounts to more than $\$ 1$ billion dollars in lost wages a year. Despite this exorbitant number, it is to be noted that it only considers the direct cost of absenteeism and would be much greater if the indirect costs could be identified (Vuorensyrja 2013).
Also a recent survey conducted by Career Builders, showed that $15 \%$ of workers are absent from work at least once a week. The number is down from $16 \%$ in 2009 and $20 \%$ in 2008. The analysis in their survey Showed that the total cost of absenteeism for the period was N56.0 million (US \$800,018). The survey posits that cost of absenteeism seemed to be higher in Delta, Kwara and Ogun states (Kola and Nelson 2009).

Anderson (2009) revealed that Though, there are many reasons given as to why an employee may be absent from work ranging from illnesses, family issues (e.g., daycare or taking care of a family member), personal issues or just feeling entitled to time off. According to the Centre for Community Health's (CCH) Unscheduled Absence Survey (2007), 13\% of people who report to work cited being stressed out as the main reason for being absent. However, several opinions on the way forward of resolving absenteeism problem were raised by researchers. Steer and Rhode (1990) stated that motivation is a major determinant 
of employee's attendance. That how often an employee comes to work is determined by the motivation he gets from the job. This opinion was supported by George and Jones' (2002) which states that job satisfaction is a major determinant of absenteeism. Obasan, (2011) further revealed that; pay, supervisor, and good conditions of service have direct effect on absenteeism. That Employees tend to be absent from work when these features are not in place.

Job design as the predicting variable of this study involves deciding the contents of a job; it fix the duties and responsibilities of the job, the method of doing the job and the relationships between the job holder and the organization (Akrani 2011). He further added that Job design also gives information about the qualifications required for doing the job and reward (financial and nonfinancial benefits) for doing the job. While designing the job, the needs of the organization and the holder must be balanced. Such needs of the organization include high productivity and quality of work, whereas the needs of the individual include job satisfaction. That is, they want the job to be interesting and challenging (Ali \& Aroosiya, 2012).

\subsection{Purpose of the Study}

The main objective of this study is to find out the extent job design is related to employee absenteeism, and the specific objectives are:

- To examine the relationship between Job enlargement and employee absenteeism

- To examine the relationship between job rotation and employee absenteeism

\subsection{Research Questions}

Base on the above objectives, the following research questions guided the study.

- What is the relationship between job enlargement and employee absenteeism?

- What is the relationship between job rotation and employee absenteeism?

\subsection{Research Hypothesis}

To find out the degree of relationship between the variables, the following two hypotheses resulting from the research questions were tested.

$\mathrm{H}_{01}$ : There is no significant relationship between job enlargement and absence intensity.

$\mathrm{H}_{02}$ : There is no significant relationship between job rotation and absence intensity

\section{Method}

The study is a cross-sectional study and as such the researchers adopted purely "descriptive survey design" to achieve the objectives of the study. This has been proven to be appropriate in a non experimental design. A descriptive survey "concerns itself with ascertaining and establishing the status-quo, facts or pieces of information at the time of the research and presenting such facts as they are" (Oputa, 2012).

The study is made up of 2,715 populations of employees in nineteen (19) ministries of the Bayelsa State Civil Service. This figure was obtained from the Bayelsa State Department of Establishment and Pension. The table below shows the numbers of workers in the various ministries.

Table 1. Names of ministries, numbers of workers and number of units apportioned.

\begin{tabular}{llll}
\hline Ministries & Numbers of Workers & Number of units Apportioned & Percentage of Workers \% \\
\hline (1) Ministry of finance & 53 & 8 & 1.9 \\
(2) Ministry of Education & 198 & 29 & 7.3 \\
(3) Ministry of Justice & 249 & 36 & 9.2 \\
(4) Ministry of Transport & 105 & 16 & 3.9 \\
(5) Ministry of Information and Orientation & 109 & 16 & 4.01 \\
(6) Ministry of Local Govt \& Community Devt. & 358 & 52 & 13.2 \\
(7) Ministry of Housing and Urban Development & 78 & 12 & 2.8 \\
(8) Ministry of Agric and natural resources & 391 & 57 & 14.4 \\
(9) Ministry of health & 160 & 23 & 5.9 \\
(10) Ministry of special Duties & 16 & 3 & 0.6 \\
(11) Ministry of Lands and survey & 42 & 7 & 1.5 \\
(12) Ministry of Youth Development & 56 & 9 & 2.1 \\
(13) Ministry of water Resources & 48 & 8 & 1.8 \\
(14) Ministry of Trade, Industry and investment & 125 & 18 & 4.6 \\
(15) Ministry of Energy & 228 & 33 & 8.4 \\
(16) Ministry of works and infrastructure & 132 & 19 & 4.9 \\
(17) Ministry of Sports Development & 46 & 7 & 1.7 \\
(18) Ministry of women \& Social Affairs & 217 & 31 & 7.9 \\
(19) Ministry of Budget \& Economic Planning & 104 & 15 & 3.8 \\
Total & 2715 & 399 & $100 \%$ \\
\hline
\end{tabular}

Voluntary response non-probabilistic sampling technique was used, and a sample size of 399 was determined using Taro Yamen's formula as shown below

$$
n=\frac{N}{1+N(\alpha)^{2}}
$$


Where $\mathrm{n}=$ sample size sought

$\mathrm{N}=$ population size

$\alpha=$ level of significance $(0.05)$

i.e. $n=\frac{2715}{1+2715(0.05)^{2}}=\frac{2715}{6.79}=399$

Also Bowley's Proportional Allocation Technique (1967) was used to determine the number of questionnaires to be distributed to the various ministries.

The formula is given as $N h=\frac{n(n h)}{N}$

Where: $\mathrm{Nh}=$ ? Number of units to be distributed to each group

$\mathrm{nh}=$ Number of respondents in each group (population of each ministries)

$\mathrm{n}=$ Total sample size

$\mathrm{N}=$ Total population size

Example. $N h=\frac{399(53)}{2715} \cdot \frac{23142}{2715}=8$

The researchers used both primary and secondary instrument for data collection; the primary source used a structured questionnaire. Part one of the questionnaires was used to obtain information on the personal data of the respondents while part two of the questionnaire was structured into 5- point Likert scale response options of Strongly Agreed (SA) Agree (A) Fairly Agree (FA) Disagree (D) Strongly Disagreed (SD); with corresponding values of $5,4,3,2 \& 1$ respectively. Copies of the questionnaire were administered with the aid of four research assistants and were collated after two weeks and the data were analyzed. On the other hand information from journals, literatures and internet material formed the secondary sources of data collection.

The research adopts content and constructs validity. Copies of the questionnaires were given to team of senior lecturers in Niger Delta University Wilberforce Island Bayelsa State Nigeria to make suggestions for improving the research instrument towards meeting the purpose of the study. The experts' suggestions were incorporated into the final draft of the questionnaire that was administered to the respondents for data collection. In order to determine the reliability of the instrument Cronbach's Alpha was used. The Cronbach for the variable investigated is shown in the table below, all fall within the accepted threshold of 0.71 as suggested by Nunally (1978).

Table 2. Table of reliability.

\begin{tabular}{lll}
\hline Variable & Cronbach Alpha & No. of Items \\
\hline Job Enlargement & 0.714 & 6 \\
Job Rotation & 0.848 & 4 \\
Absence Intensity & 0.714 & 5 \\
\hline
\end{tabular}

Out of 399 copies of questionnaires administered, 368 were retrieved, after the sorting process only 348 were useful. The researchers used descriptive statistic and the results presented on tables. Whereas, the strength of the relationship between the independent and dependent variable was analyzed using spearman ranking Order correlation coefficient and the impact of the moderating variable on the relationship between the independent and dependent variable using partial correlation.

\section{Result}

\subsection{Analysis on Demographic Characteristics}

The demographic analysis entails descriptive statistics using frequencies and percentages in describing the characteristics of the sample.

Table 3. Gender demographic characteristic.

\begin{tabular}{lll}
\hline Gender & Male & Female \\
\hline Frequency (percentage) & $230(66 \%)$ & $118(34 \%)$ \\
\hline
\end{tabular}

Table 3. shows the gender demographic distribution for the study with the male gender category having a larger percentage of respondents when compared to their female counterpart. This could be as a result of the work expectations, presence of faulty or biased recruitment practices, and the glass ceiling effect which is a prevailing situation in most Nigerian organizations or probably a poor attitude of female staff towards involvement in the research activity.

Table 4. Position demographic characteristic.

\begin{tabular}{lll}
\hline Position & Senior Staff & Junior Staff \\
\hline Frequency (percentage) & $140(40 \%)$ & $208(60 \%)$ \\
\hline
\end{tabular}

Table 4. shows the demographic distribution for position with most staff in the junior staff category, an obvious reason situation based on the nature and structuring of organizations which allows for fewer staff at the senior position compare to the junior positions.

Table 5. Experience demographic characteristic.

\begin{tabular}{llll}
\hline Experience & I $-\mathbf{5}$ years & $\mathbf{6}-\mathbf{1 0}$ years & $\mathbf{1 1}$ years and above \\
\hline $\begin{array}{l}\text { Frequency } \\
\text { (percentage) }\end{array}$ & $70(20 \%)$ & $180(51 \%)$ & $98(29 \%)$ \\
\hline
\end{tabular}

Table 5. shows the demographic distribution for staff work experience with a greater percentage having experience ranging from $6-10$ years which also reflects the absent rate in the ministries.

Table 6. Qualification Demographic Characteristic.

\begin{tabular}{lllll}
\hline Qualification & $\begin{array}{l}\text { FSLC/ } \\
\text { SSCE }\end{array}$ & NCE/OND & $\begin{array}{l}\text { HND/BSc } \\
\text { Degree }\end{array}$ & $\begin{array}{l}\text { Master's/Ph.D } \\
\text { Degree }\end{array}$ \\
\hline $\begin{array}{l}\text { Frequency } \\
\text { (percentage) }\end{array}$ & $30(9 \%)$ & $100(28 \%)$ & $174(50 \%)$ & $44(22 \%)$ \\
\hline
\end{tabular}

Table 6. shows the demographic distribution according to qualification with most of the respondents having attained first degrees; a strong indication of the educational level and possible reliance on qualifications for promotions, wage increment and the likes within the ministries.

\subsection{Analysis on Variable Characteristics}

The variables are in this section analyzed using descriptive 
statistics bothering on central tendencies and dispersion. Analysis is for each variable is carried out using mean and standard deviation and is aimed at illustrating the distribution of each variable. The predictor variable; Job Design is operationalized through Job enlargement and Job rotation, while the criterion variable; Employee Absenteeism is operationalized using absence intensity.

Table 7. Distribution of study variables.

\begin{tabular}{lll}
\hline Variables & Mean Score & $\begin{array}{l}\text { Standard } \\
\text { Deviation }\end{array}$ \\
\hline Job Design (predictor) & 3.9674 & 0.80613 \\
Job Enlargement & 3.9272 & 0.76117 \\
Job Rotation & 3.9152 & 0.98968 \\
Employee Absenteeism (Criterion) & 3.9108 & 0.61744 \\
Absence Intensity & 3.9272 & 0.76117 \\
\hline
\end{tabular}

Table 7. showing the distribution of each variable based on average mean responses to indicators and standard deviation values. All mean score values are tend relatively towards the positive and suggest affirmative responses from the respondents with corresponding standard deviations scores which are all below 1.00. figures show a significant level of agreement with the least average mean score at 3.9272 (absenteeism) which still holds strong affirmative tendencies based on the adoption of the 5 - point Likert scaling method ranging from a negative pointer of 1 (strongly disagree) to the positive or affirmative pointer of 5 (strongly agree).

The corresponding standard deviation values are also indications of a low level of disparity in responses as against the mean values; a good indication of high levels of response uniformity and coherence especially as regards each variable.

\subsection{Test of Hypotheses}

The tests for the bivariate hypotheses are carried out using the Spearman's Rank Order Correlation Coefficient analytical tool. The study adopts the 0.01 significance level as criterion for rejection or acceptance of the null bivariate hypothetical statements presented in Tables 8 and 9.

Table 8. Nonparametric correlation of job enlargement and absence intensity.

\begin{tabular}{|c|c|c|c|c|}
\hline & & & Job enlargement & Absence intensity \\
\hline \multirow{6}{*}{ Spearman's rho } & \multirow{3}{*}{ Job enlargement } & Correlation Coefficient & 1.000 & $.823 * *$ \\
\hline & & Sig. (2-tailed) & . & .000 \\
\hline & & $\mathrm{N}$ & 348 & 348 \\
\hline & \multirow{3}{*}{ Absence Intensity } & Correlation Coefficient & $.823 * *$ & 1.000 \\
\hline & & Sig. (2-tailed) & .000 & . \\
\hline & & $\mathrm{N}$ & 348 & 348 \\
\hline
\end{tabular}

**. Correlation is significant at the 0.01 level (2-tailed).

The table 8 illustrates the tests for hypotheses one $\left(\mathrm{HO}_{1}\right.$ : There is no significant relationship between Job enlargement and Absence Intensity). At a $99 \%$ confidence interval, the results show significant relationships between Job enlargement and Absence Intensity $\mathrm{HO}_{1}$ (rho: 0.823, p-value:
0.000). Therefore based on the result, null hypotheses one is rejected and we restate that:

- There is a significant relationship between Job enlargement and Absence Intensity

Table 9. Nonparametric correlation between job rotation and absence intensity.

\begin{tabular}{lllll}
\hline & & Job Rotation & Absence Intensity \\
\hline & \multirow{3}{*}{ Job Rotation } & Correlation coefficient & 1.000 & $.794^{* *}$ \\
Spearman's rho & & Sig. (2-tailed) & & .000 \\
& & $\mathrm{~N}$ & & 1.000 \\
& Absence & Correlation Coefficient & $.794^{* *}$ & \\
& Intensity & Sig. (2-tailed) & .000 & 348 \\
\hline
\end{tabular}

** Correlation is significant at 0.01 level (2-tailed)

The table 9 illustrates the tests for hypotheses three (HO2: there is no significant relationship between Job Rotation and absence Intensity). At a $99 \%$ confidence interval, the results show significant relationships between Job Rotation and absence Intensity HO2 (rho: 0.794, p-value: 0.000). Therefore based on the result, null hypotheses two is rejected and we restate that:

- There is a significant relationship between Job Rotation and absence Intensity.

\section{Conclusion}

The results from the study show that there is a significant relationship between job design and employee absenteeism. As a result of this, the following conclusions are drawn:

- The effective design of employees job is a necessary ingredient in improving employee's attendance rate thereby curtailing their level of absenteeism thus it will enhance the employee productivity and profitability to 
the organization in the long runs.

- Job enlargement is a veritable tool in making employee acquire variety of skills and experience thereby making them have intrinsic satisfaction of their job which in turn would improve their commitment level to the organization including being regular and punctual to work.

- Job rotation is imperative in achieving a more fulfilling career experience and also offers employees the opportunity to grow as a result of learning and work experience.

\section{Recommendations}

On the basis of conclusions derived from this study, the following recommendations are made:

a. Organizations including the ministries should take effective job design as a priority, and deliberate effort should be made to achieve its workability through job enlargement and job rotation.

b. Organizations should seek to make their employee's job interesting and challenging, this will make them have satisfaction and improve their commitment level to reduce every form of negative attitude towards their job including absenteeism.

c. Organizations should institute relevant policies, Norms and values which supports the design of their employee's job to achieve efficiency and individual accomplishment.

d. Organization should redesign the job of its employee in such a way that it keeps them engaged on daily basis so as to reduce their absence rate, and tardiness towards their work.

\section{References}

[1] S. Rhodes, \& R.M. Steers, (1990) Managing employee absenteeism. New York: Addison-Wesley.

[2] C. Vuorensyrja (2013), The cost of employee absenteeism. Integrity management Group.

[3] A. Kola, and E. A Nelson (2009). Cost analysis of teacher absenteeism in Nigerian

[4] Secondary Schools. Journal of Social Science, 21(2): 137-144 (2009)

[5] Centre for Community Health's (CCH) (2007). Unscheduled absence survey. Retrieved: www.cch.com/press/news/2008/20080110h.

[6] J.M. George, \& G.R Jones. (2002). Organizational behavior. (3rd ed.). New Jersey:Prentice hall.

[7] K A. Obasan. (2011). Impact of job satisfaction on absenteeism:A correlative study. European Journal of Humanities and Social Sciences

[8] Akrani (2011). Job design definition: wikipedia the free encyclopedia

[9] C. C. Oputa (2012). Research Methods \& project/Thesis/Dissertation writing Guide Part 2 ( $2^{\text {nd }}$ Ed.). $\mathrm{C}^{2}$ International Company Publsisher, Port-Harcourt.

[10] Bayelsa state establishment \& pension (2014). Number of ministries and estimated staff strength report.

[11] J.C. Nunally (1978). Psychology Theory, New York; Mc Grow-Hill

[12] H. Ali \& M. Aroosiya (2012). Impact of job design on employees' performance. Retrievedfromhttp://www.kln.ac.lk/fcms/ICBI2012/images/IC BM/dccs/Microsoft\%20Word\%20-\%20HRM013.pdf 